\title{
STABILIZATION OF THE VISUAL FIELD ${ }^{1}$
}

\author{
LORUS J. MILNE AND MARGERY MILNE
}

Department of Zoology, University of New Hampshire, Durham, New Hampshire

Most animals can make no adjustment in the orientation of their principal visual organs in relation to the body. Those that can move their eyes separately are the vertebrates, virtually all of the cephalopod mollusks, many crustaceans, and the comparatively few kinds of insects that have a mobile head. A remarkable number of these animals use this ability in a paradoxical way. They move their eyes in relation to the body to prevent their eyes from moving in space. Involuntary movements of their eyes tend to stabilize their visual field.

The anatomical basis for these adjustment is well known among vertebrates, which uniformly possess a conical array of four rectus muscles, and two oblique muscles in the orbit of each eye. Involuntary oscillatory adjustments (nystagmus) of the eye, chiefly through contractions of the external and the internal rectus muscles, have been noted for many years in man and some other vertebrates, elicited by visual stimuli. The obliques provide a correcting system that smooths out the horizontal and vertical sweeps produced by the antagonistic rectus muscles. They also produce "wheel movements" (Raddrehungen, Augenrollungen, cyclorotations) that confer on the organ a third degree of freedom. With its obliques, an animal may also be able to correct for skewness in its visual field. Involuntary responses of this kind follow stimulation of sensory centers in the muscles of the human neck (Nagel, 1896; Zoth, 1905), and in the inner ears of several other vertebrates (Benjamins, 1918, 1920; Magnus and de Kleyn, 1921). These adjustments based upon proprioceptive and gravitational cues show a latency in milliseconds, and commonly depend upon the obliques acting alone.

Voluntary use of the rectus muscles in opposing pairs is found in some but not all vertebrates, and serves to keep centered in the visual field any object that moves. This following is usually jerky, with momentary pauses for fixation. Only these voluntary movements are discussed under ocular motility in The Vertebrate Eye and Its Adaptive Radiation (1942) by the late Gordon L. Walls, and in Les Yeux et la Vision des Vertébrés (1943) by the outstanding French ophthalmologist A.-J.-F. Rochon-Duvigneaud. The latter divided reptiles into a category with immobile eyes (the snakes, geckos, and crocodilians) and another with mobile eyes (most lizards and chelonians). The true rarity of voluntary movements presumably led Sir Stewart Duke-Elder in his comprehensive volume, The Eye in Evolution (1958), to comment that most birds have fixed eyes and compensate for this fixity by bending their necks to follow objects of interest.

Benjamins (1918) rotated a live perch about a transverse axis and recorded the wheel movements of its eyes (Fig. 1A). When the anterior end of the fish was

1 Presented before the Fourth International Congress on Photobiology, at Oxford, England, July 27, 1964 . 
raised, to a position matching that assumed by the animal while feeding at the surface, compensatory rotation of its eye maintained the horizontality of the horizon to about 10 degrees, and then failed progressively to maintain correspondence as the angle between the longitudinal axis of the body and the horizontal was increased (Fig. 1B). A maximum rotation of 28 degrees in this direction was reached when the body reached a 70-degree angle with the horizontal. Stability of the visual field was never as good when the anterior end of the fish was depressed, as it would be while the animal feeds from the bottom. A maximum rotation of the eyes was reached at 35 degrees when the body made an 80-degree angle with the horizontal. Curiously, the cyclorotational correction vanished
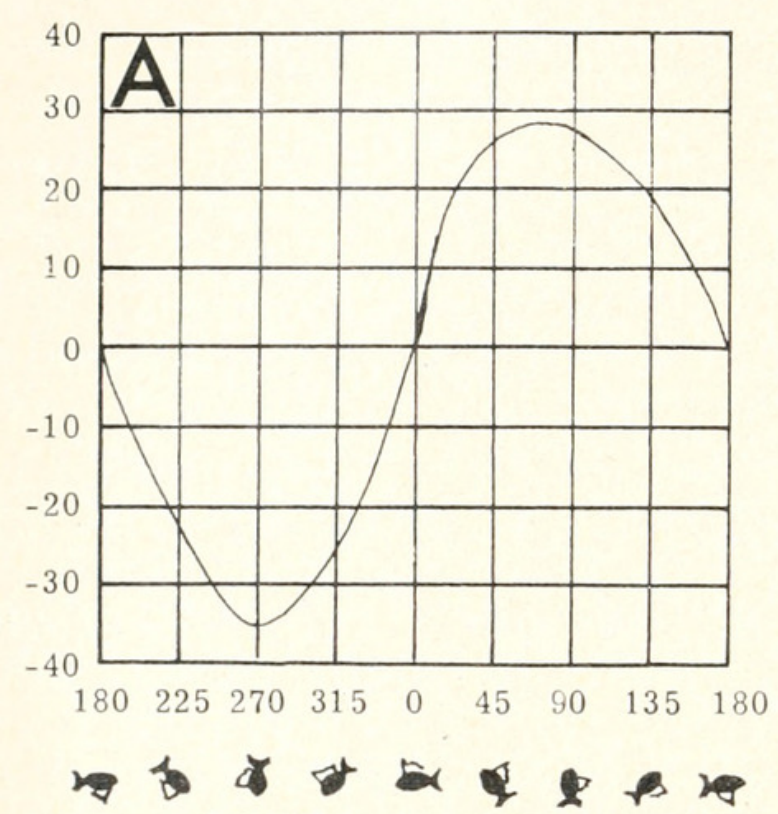

head down head up

inverted
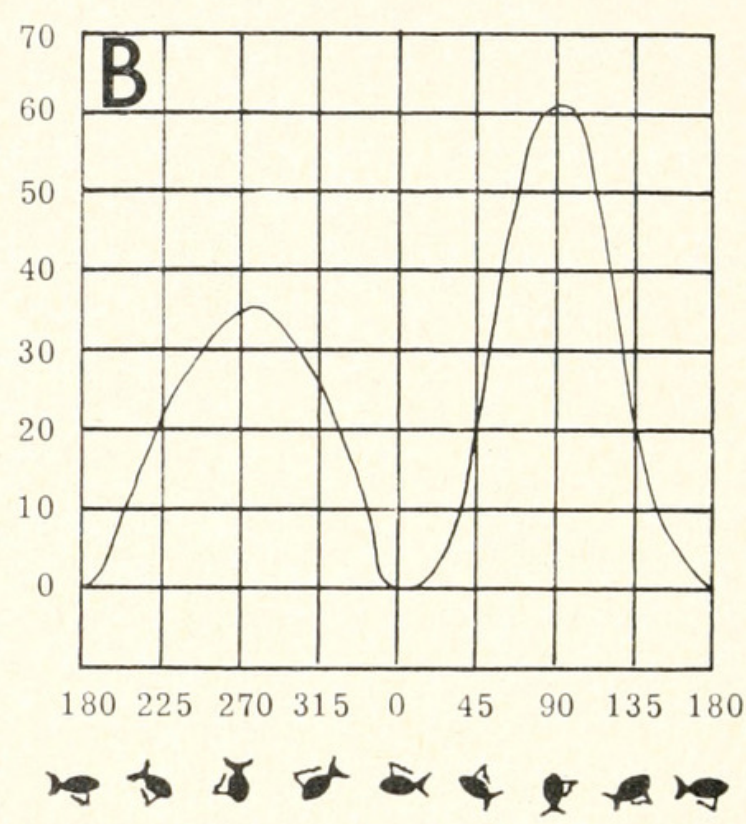

head down head up

Figure 1. When a European perch is rotated slowly about a transverse axis, its eyes exhibit compensatory rotational adjustments with respect to the body $(A)$, but fail to hold the visual field level $(B)$ except within about 8 degrees with head raised, about 5 degrees with head lowered, and about 1 degree with the body completely inverted. (Replotted from data of Benjamins, 1918.)

when the fish was inverted and its longitudinal axis again lay in the horizontal plane. These involuntary responses appear to depend entirely upon stimulation of the maculae of the inner ear.

Magnus and de Kleyn (1921) found remarkable excursions of the eyes in European rabbits, according to the static position of the inner ears. It made no difference whether the whole animal was tilted or only its head was turned. Compensatory rotations of its eyes tended to stabilize the visual field within a degree or less over a range of head positions nearly 100 degrees in any direction. Beyond this limit, the rabbit's eyes tended to remain in their position of maximum excursion, and the animal showed a lessened response to visual stimuli.

Involuntary cyclorotation of the eyes in a reptile came to public notice through some observations of the copperhead snake (a pit viper of America) made by Professor D. F. Munro of Kansas State College and communicated by him to Albert G. Ingalls (Scientific American, March, 1954). Munro had noted that the vertical slit pupils of this snake remain vertical even when the reptile's head is 
raised at an angle of 65 degrees, or lowered a like amount. He reported further that just before dozing, the snake let the anterior pole of each eye rotate ventrad by about 10 degrees. When the snake was actually asleep, its pupils again took on a vertical orientation, but with the whole eye rotated until only the top of the pupil was visible through the corneal scale (Fig. 2).

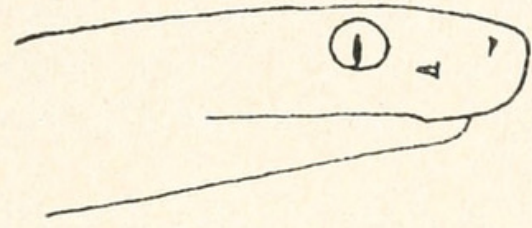

Normal alert position

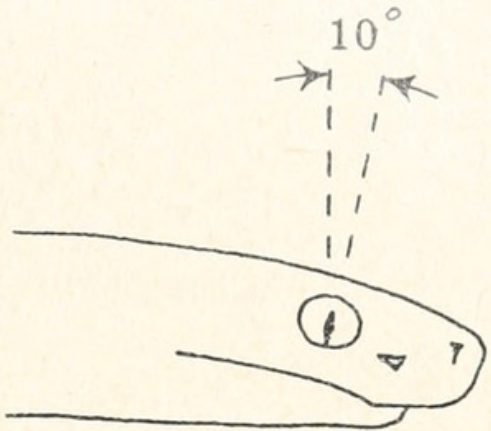

Just before dozing
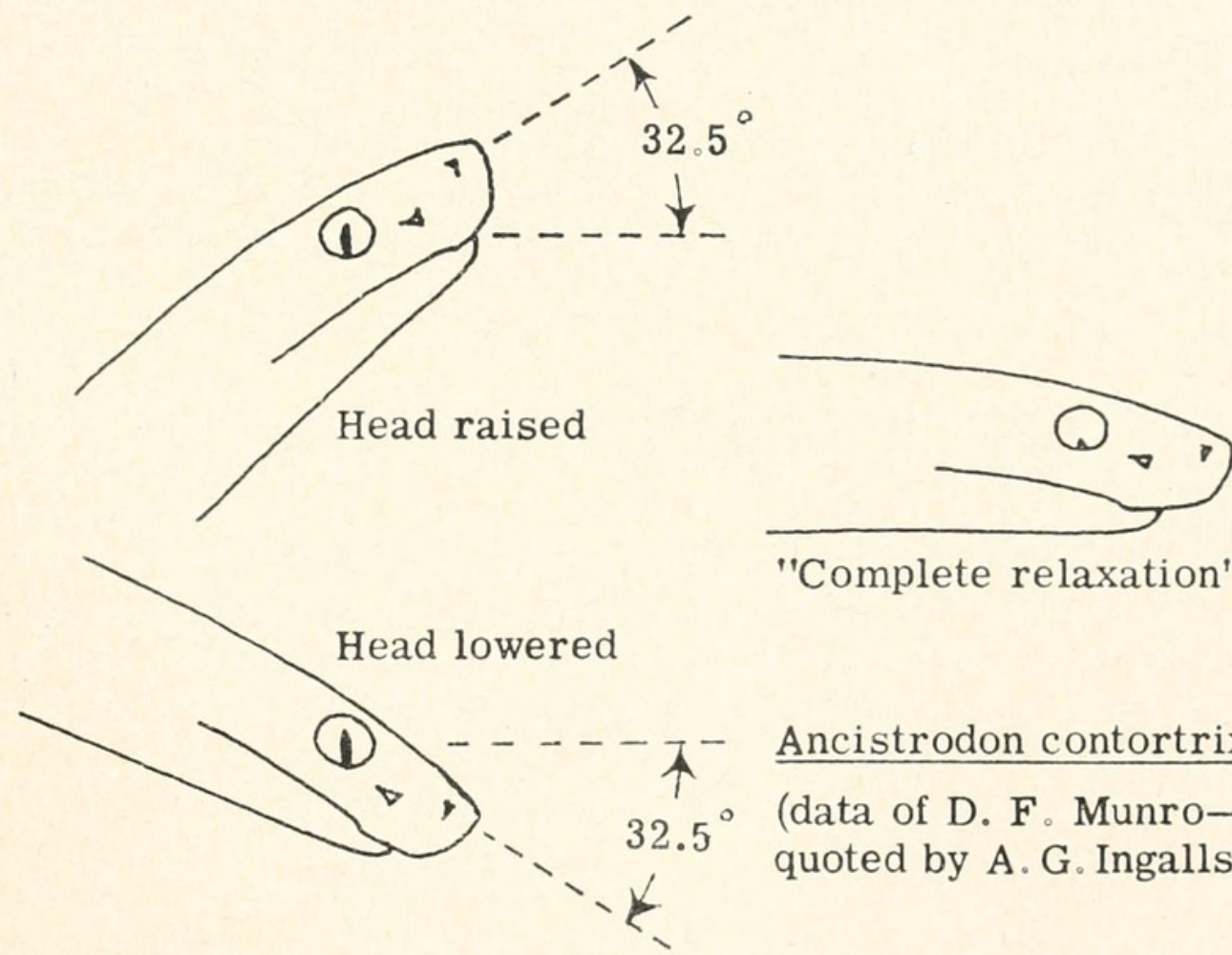

"Complete relaxation"

Ancistrodon contortrix

(data of D. F. Munroquoted by A. G. Ingalls)

Figure 2. Rotational movements of the eye in the copperhead snake. (Data of D. F. Munro, prepared by permission from an illustration. Copyright (C) 1954 by Scientific American, Inc. All rights reserved.)

In a subsequent issue of the same magazine (November, 1954), Ingalls published further information on cyclorotation, with observations made by Henri Morgenroth, a consulting engineer of Santa Barbara, California. The new data offered by Morgenroth related to a young turtle and a goldfish, and drew forth an additional comment from Professor Munro to the effect that stabilization of the visual field by cyclorotation is found also in snakes that do not strike at prey. One with a vertical oval pupil (unidentified) was cited as showing stability of eye orientation with respect to the field over a range of head position from 27.5 degrees below to 27.5 degrees above the horizontal. 
For the eye of the pigeon, Whitteridge (1956) found a rotational correction amounting to about 10 degrees for head positions with the beak raised or lowered beyond the normal orientation. He did not establish whether the adjustment was a response to stimuli detected in the inner ears or in neck muscles. In man, the neck receptors alone call forth the response, and no stabilization of the visual field is gained if the whole trunk and head are inclined together to right or left.

Analogous mechanisms can be recognized among several types of invertebrates. The slit pupil of the European Octopus vulgaris has long been seen to remain horizontal despite movements of the body over irregular obstacles (Magnus, 1902; Muskens, 1904; van Weel and Thor, 1936). These responses are obliterated if the statocysts are destroyed or the nerves from them are cut (Young, 1960). No measurements of the maximum rotational adjustments possible seem to have been published for this cephalopod.

Compensatory movements of the eyes have been observed also in crustaceans. When the mantis shrimp, Squilla, crawls up over an obstacle, it allows its eyestalks to droop (Demoll, 1909). The rotations of the almost spherical median compound eye of Daphnia, under rather jerky control of four oculomotor muscles, are a counterpart on a smaller scale (Ewald, 1914).

Since no systematic account of mechanisms providing stability to the visual field has yet appeared, we decided to collect together the scattered observations (and measurements) from the literature and to fill in gaps as opportunities allowed.

\section{Materials and Methods}

Where possible, we have obtained photographic records of the extent of compensatory cyclorotation in a variety of living invertebrates and vertebrates (Table I). In some instances, as with the sand shark, Carcharias, it was inadvisable to molest the animal for the sake of discovering the fullest extent of possible compensation by displacing its body from its normal relationship to the horizontal plane. We photographed the shark at those times when it chose to pass the portholes of a large oceanarium tank, while it was swimming in a strongly nose-up or nosedown position. The values cited in the table for the shark are taken from $16-\mathrm{mm}$. motion pictures. For measurement we selected those frames in which the lens of the camera appeared to be facing the shark along the transverse axis from eye to eye. Other values cited in the table represent the maximum excursion noted. In all instances from our own studies, the maximum was reached before the animal's body was rotated 90 degrees about a transverse axis from its normal attitude with respect to the horizontal plane. We did not explore for any animal its rotational responses to body attitudes more than 90 degrees away from normal, since such extremes seem improbable under natural conditions. We may thus have overlooked counterparts of the phenomenon reported for the tadpole of the frog, Phyllomedusa, in which the eye locked in its normal orientation when the animal was turned on its back (Quesnel, 1956).

\section{RESUlts}

\section{Vertebrates}

Among the animals tested, only the spectacled caiman showed oscillatory rotational adjustments (a "cyclonystagmus") for several minutes whenever held with 


\section{TABLE I}

Cyclorotational compensatory adjustments retain an essentially stable visual field to the limits shown, except in Perca, for lateral bending of the neck (in Homo) or for elevating $(+)$ or depressing (-) the anterior end of the body. Reference points for detecting cyclorotation can be found in pigment flecks on the iris in Homo, Oryctolagus, Columba,

Perca, and Cyprimus; in the vertical slit pupil of Caiman, Ancistrodon, Constrictor, and Hemidactylus; in a horizontal black stripe through sclera and iris in Pseudemys, Pseudotriton, and Necturus; in a vertical oval pupil in Bufo, Rana, and Carcharias; in a nick in the ventral edge of the circular pupil in Phyllomedusa; and in a horizontal slit pupil in Sepioteuthis

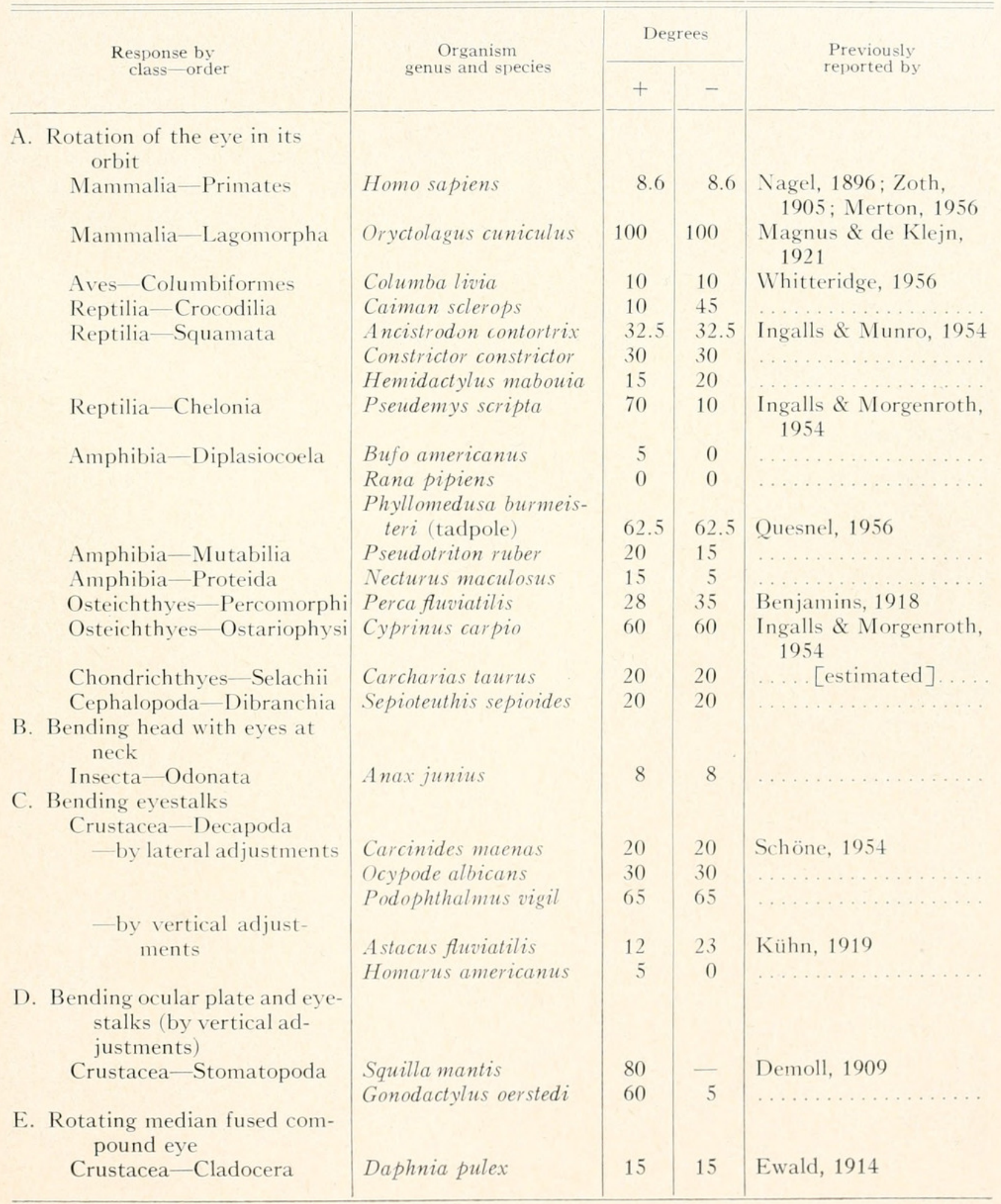


its head raised more than 10 degrees or lowered more than 50 degrees. Possibly when this animal is allowed to move freely, it seldom assumes these attitudes.

\section{Cephalopods}

The same limits for cyclorotation were noted in the squid, Sepioteuthis, when specimens were restrained by hand in a marine aquarium and when free to move undisturbed. Unrestrained squids in captivity often assume attitudes approaching the extremes for which their cyclorotational compensation seems adequate. Less extreme positions were observed under natural conditions over the reef, upon those occasions when small schools of squid passed close to us as we watched horizontally through glass face plates while submerged.

\section{Insects}

The value shown in the table for the dragonfly, Anax, with its anterior end depressed is close to the limit imposed by contact between head and thorax. Possibly this attitude is unusual for the insect, whether at rest or in flight. Compensatory movements that might stabilize the visual field were looked for but never found in the introduced mantis, Paratenodera sinensis. Mantises appear to look about themselves alertly, making wide use of a flexible neck. They also cling in many positions while waiting for prey. Females stand head downward while producing an egg mass.

\section{Crustaceans}

Among decapod and stomatopod crustaceans, the eye movements that tend to stabilize the visual field are of different types according to the normal manner of progression shown by the animal. For crabs which run from side to side, the pertinent movements of the eyestalks are those shown when the crab goes sidewise up or down a slope. For crayfishes, lobsters, and stomatopods, all of which progress forward when hunting and backward when escaping, the comparable changes in attitude of the eyes are those that match elevation or depression of the anterior end (the head) with respect to the abdomen.

Among crabs, the tendency is to maintain vertical the whole eyestalk or that part bearing the compound eye. Among crayfishes, lobsters, and stomatopods, the eyestalk is more commonly held almost horizontal. In each species examined, these orientations of the eyes are maintained well during changes in body position within the limits cited in Table I. Gravity is presumed to determine the orientation, since it is maintained in complete darkness.

In the cladoceran, Daphnia, by contrast, gravity appears to have no role in responses involving the oculomotor muscles. These muscles respond only when the pattern of illumination on the ommatidial cluster meets certain specifications. No eye movements are elicited under uniform red light to which Daphnia is insensitive (Ewald, 1914), or when unpolarized light reaches the animal from above the water while Daphnia is in its upright swimming position. If either the light comes from a different angle or the Daphnia is differently oriented, ommatidia other than the "usual" ones appear to receive greater stimulation. The eye is then 
rotated, and swimming movements show adjustments that bring the animal into the orientation in which no further compensatory rotation is called for.

\section{Discussion}

Mechanisms that tend to stabilize the visual field while the head or body is displaced from its commonest orientation in space all have one adaptive value. They aid the eyes in bringing to the brain a pattern it may recognize, as the basis for a response that may have survival value to the animal.

Among non-primates, where reactions to specific patterns in the visual field appear to be innate, this matching of information from the eyes with the central identification system would seem particularly important (Morgenroth, as quoted by Ingalls, 1954). Even where conditioned responses develop readily, the orientation of the pattern with respect to the horizontal plane may be important. Supposedly this is the basis for the ability shown by a captive Octopus to learn that a reward lay behind a horizontal rectangle but punishment behind a vertical one (Boycott, 1954). It retained the ability to discriminate so long as its statocysts and the nerves connecting them to the brain were intact. Ability to make compensatory cyclorotations of the eyes in relation to altered orientation of the body also vanished permanently when the statocysts were destroyed or their nerve connections cut.

People, too, learn to identify patterns quickly in one orientation and sequence, and have difficulty transferring this learning to a different orientation or a different sequence. For any person trained in a Western alphabet, the sequence of left-toright seems more important than inversion. If forced to read a printed page from a mirror image or upside down, we decipher the familiar words slowly and laboriously. A printer avoids this difficulty when he sets type by hand, working from left to right with the top of all characters toward him. In this orientation he can proof each line of type quickly, recognizing every letter inverted but in its normal sequence.

Similarly, the lettering on the backbone of a book is read far more quickly if we can turn our head 90 degrees and see the letters in customary relationship, side-by-side, than if the letters are placed one above the next and must be read from top to bottom with our head in its upright position. Visual acuity falls off rapidly if our scanning movements must follow unusual directions (Merton, 1956).

For insects, the orientation of a pattern in relation to the horizontal plane may be far less important than other sensory cues derived from the relative attitudes of the head and body. When Miss Mathilde Hertz showed (1929-1934) that the honeybee readily confuses patterns having the same general ratio of perimeter to area, biologists were somewhat surprised. But now it is clear that this insect discriminates among the patterns it encounters with no need to turn its head, and gains from relative movements of head, thorax, and abdomen a multitude of cues important in maintaining stability in flight (Lindauer and Nedel, 1959). In this respect it parallels the sensory system in a dragonfly (Mittelstadt, 1950) whose delicately-held massive head maintains its orientation in space through inertia despite vertical currents of air that tilt the outstretched wings. Although a dragonfly can bend its head as much as 25 degrees to reach with its mouth for insects caught among its forward-reaching legs, it shows little of the compensatory rotation of the head that the flexible neck makes possible. While clinging to a vertical reed, 
the dragonfly ordinarily holds its head much as it does in flight, with the sensory pads on the sides of its neck within grazing distance of skeletal projections on the head and thorax. Reflexes mediated through these pads are called forth whenever the head and thorax are out of line. They normally lead to changes in wing movements that bring the dragonfly back to a straight and level flight path.

Among crustaceans with stalked eyes, analysis is complicated by the fact that the eyestalk fundamentally consists of two segments. The distal one is the "calathus" of Young (1959), and bears the compound eye. The proximal segment, next to the cephalothorax, is greatly reduced in most decapods. But in a few the proximal segment is far longer than the distal one and the crab gains from flexibility between the two.

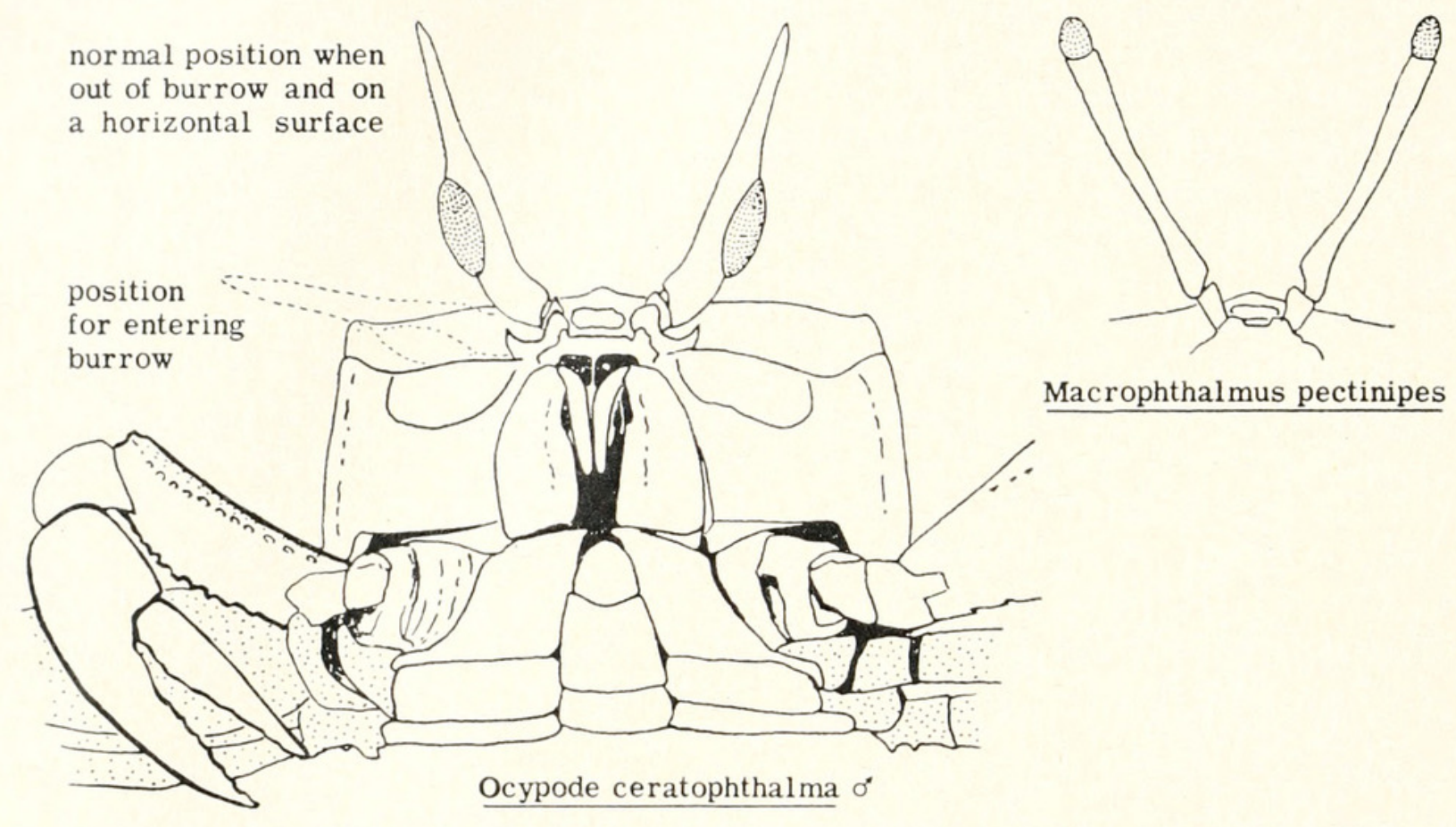

Figure 3. Lateral adjustments of the eyestalk are used to stabilize the visual field in the ghost crabs, Ocypode ceratophthalma and Macrophthalmus pectinipes. In both, the proximal segment of the eyestalk is greatly reduced, and movements involve only the elongated distal segment.

The ghost crabs, Ocypode ceratophthalma and Macrophthalmus pectinipes (Fig. 3 ), show special development of the distal segment. Like Ocypode albicans, these terrestrial crabs tend to stabilize their visual field over a wide range of body positions. To do so they use the same muscles that serve to raise and lower the eyestalks into the protective groove across the anterior edge of the carapace. When a ghost crab begins the downward slant into its burrow in the beach, it quickly lowers the eyestalk on the advancing side and then the eye on the opposite side as it enters the hole. Upon return to the surface the crab raises its eyestalks vertically at once, then drops them part way into the groove while quickly wiping them clear of sand with the flexible tips of the third maxillipeds. Orientation of the eyestalks appears to depend upon specialized sensory hairs in the statocyst which is present in the proximal segment of the antennules (Dijkgraaf, 1955, 1956 ; Schöne, 1951, 1954, 1959; Cohen, 1960). Statoliths are lacking (Bethe, 1897). 
A similar mechanism appears to control the distal segment of the eyestalks in Podophthalmus and Euphylax, which possess statocysts with specialized hairs but no statoliths. In these marine crabs of shallow coastal water, the proximal segment of the eyestalk is greatly elongated, whereas the distal segment is scarcely larger than the compound eye (Balss, 1940). According to Mr. Bryant Sather (personal communication), Podophthalmus vigil of Hawaii holds its proximal segments at 45 to 50 degrees above the horizontal by day, and about 10 degrees at night (Fig. 4). When feeding in silt that envelops the body completely, Podophthalmus may raise its proximal segments to a still greater angle, perhaps
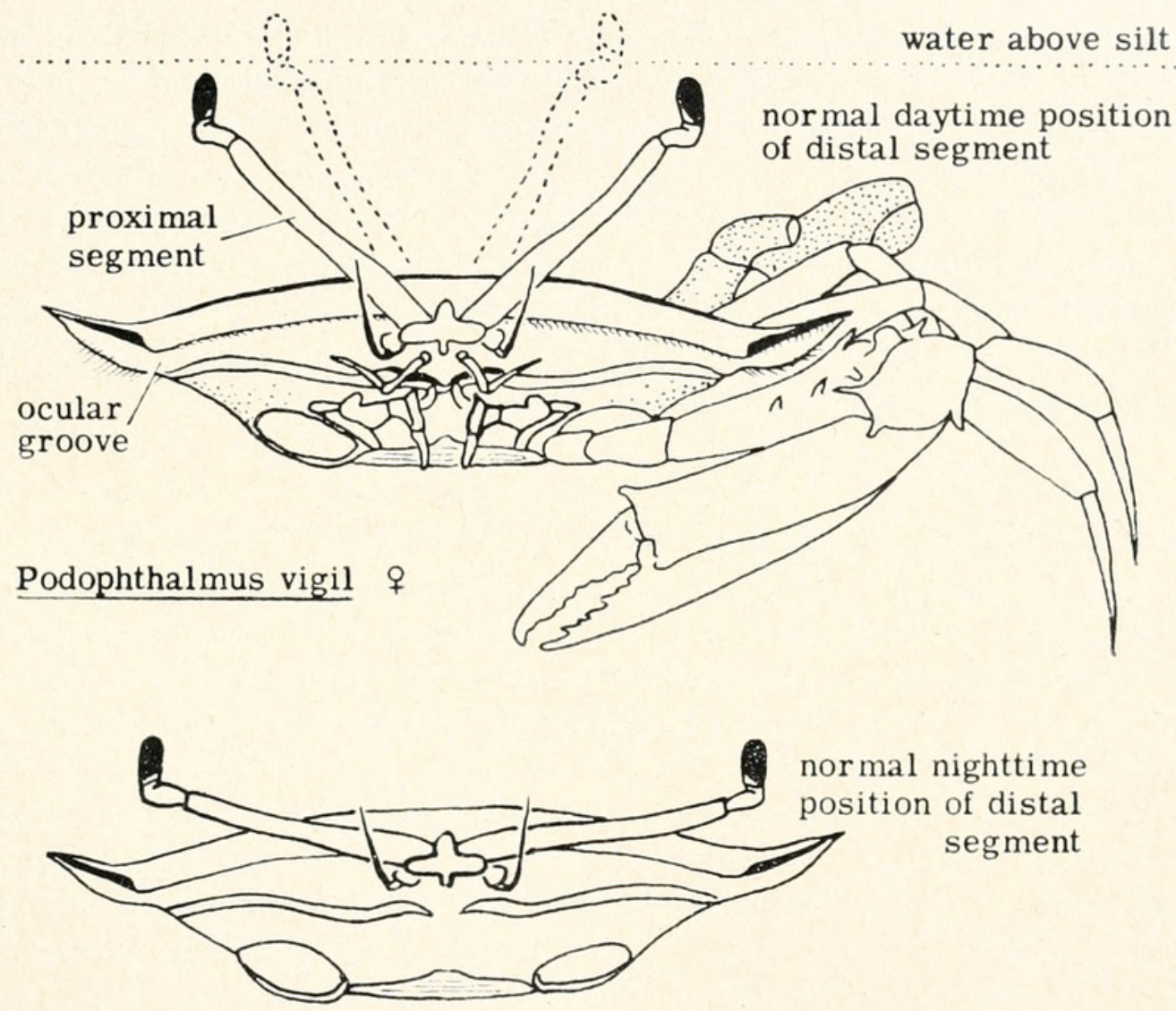

Figure 4. The Hawaiian crab, Podophthalmus vigil, maintains the verticality of the distal segment of each eyestalk while moving about with the proximal segments raised by day or partly lowered at night, and while moving sidewise over an inclined surface. (Data from Sather, 1962.)

65 degrees. Often this suffices to keep its compound eyes in clear water above the silt, where vision is possible. Both at night and when the proximal segments are elevated into daytime position, the distal segments are kept vertical. Only when the crab is lifted out of the water or its eyestalks are molested is the distal segment lowered into the protective groove across the anterior edge of the broad carapace. Thus, the elongated proximal segments serve to raise the eyes high above the body of this silt-dwelling crab, while muscular adjustments of the short distal segment stabilize the visual field.

Sand grains, serving as statoliths in the antennular statocysts of crayfishes and lobsters, appear necessary in the sensory system that permits these animals to right themselves and make compensatory adjustments of their eyestalks to 
match rotational displacements of the body (Kuhn, 1919; Schöne, 1954). But when the lobster, at least, walks over an irregular bottom and raises its anterior end to surmount some obstacle, its eyestalks droop only slightly. No compensatory movements of the eyes are apparent when the lobster descends a slope.

Stomatopod crustaceans lack statocysts altogether (Demoll, 1909; Balss, 1938), and make most of their compensatory adjustments by lowering the eyestalks in relation to the ocular plate, which is a hinged forward portion of the head region. These adjustments, which are conspicuous while the animal crawls up over some obstacle, occur at the same time that the eyestalks are performing scanning movements (Milne and Milne, 1961).

Organization of the compound eye in the cladoceran, Daphnia, is on an utterly different plan. The 22 ommatidia are radially arranged around a median mass that arises by fusion of a pair of embryonic rudiments. With so simple a compound eye, Daphnia can gain only the crudest resolution from its field of view. The structure is at least two orders of magnitude simpler than any of the other animals discussed above. Seemingly the compensatory movements of the eye, which the four oculomotor muscles control, are unrelated to any feature of the field of view other than the most intensely illuminated part, and the principal plane of polarization if this is detectable.

We are particularly grateful to Mr. Bryant Sather, Department of Zoology, University of Hawaii, for his notes on Podophthalmus and specimens of this remarkable crab. Our own observations on Caiman and Constrictor were made at the University of the West Indies, Mona, St. Andrews, Jamaica, B.W.I., through the courtesy of Mr. Garth Underwood; on Hemidactylus and Sepioteuthis at the Bellairs Marine Laboratory of McGill University, Barbados, B.W.I., with assistance from Dr. John Lewis; on Carcharias at Marine Studios, Marineland, Florida; on Ocypode and Gonodactylus at the Lerner Marine Laboratory of the American Museum of Natural History, Bimini, Bahamas, B.W.I.; on the musculature of Squilla from large specimens generously furnished by Dr. Carl N. Shuster, Jr., now of the Northeast Shellfish Sanitation Research Center, Davisville, R. I.; and on Bufo, Rana, Pseudotriton, Necturus, and Homarus at the University of New Hampshire. Travel costs were defrayed in part by research grants from the Explorers Club, the Society of the Sigma Xi, and the Central University Research Fund of the University of New Hampshire.

\section{SUMMARY}

1. Stabilization of the visual field through cyclorotational movements of the eyes has been recorded in representatives of all major groups of vertebrates and in cephalopod mollusks possessing camera-style eyes. New data are offered on Caiman, Constrictor, Hemidactylus, Bufo, Rana, Pseudotriton, Necturus, Carcharias, and Sepiotenthis.

2. Comparable adjustments in the movable stalked eyes of crustaceans have been noted in both brachyuran and macruran decapods and in stomatopods. New data are offered on Ocypode, Podophthalmus, Homarus, and Gonodactylus. The silt-dwelling crab, Podophthalmus, represents an extreme, in which the elongated 
proximal segment of the eyestalk raises the terminal segment high above the body, while the terminal segment is stabilized in relation to gravity and usually extends above the silt into clear water.

3. Movements of the head in insects that have a flexible neck appear to relate less to stabilization of the visual field than to feeding, cleaning the legs and body, or recovery of normal flight attitude after displacement by air currents. Orientation of patterns in space seems to have less significance than other parameters of important patterns. Some compensatory movements of the head are reported for dragonflies (insect order Odonata) but not for mantises (order Orthoptera).

4. Oculomotor activity of the median compound eye in the cladoceran Daphnia shows no definite relationship to gravity. Its responses to light represent a much lower order of reaction to the environment than is noted in malacostracan crustaceans with mobile compound eyes.

\section{LITERATURE CITED}

Balss, Heinrich, 1938. Stomatopoda. In: Dr. H. G. Bronns Klassen und Ordnungen des Tierreichs. Ed. by A. Schellenberg and T.-E. Gruner. Akademische Verlagsgesellschaft, Leipzig. vol. 5, pt. 1, book 7, pp. 1-173.

Balss, Heinrich, 1940. Decapoda. Ibid., vol. 5, p. 1, book 7, pp. 1-160.

Benjamins, C. E., 1918. Contribution à la connaissance des réflexes toniques des muscles de 1'oeil. Arch. Néerland. Physiol., 2: 536-544.

Benjamins, C. E., 1920. Versuche über Otolithenentfernung. Ber. gesampte Physiol., 2: 176.

Bethe, Albrecht, 1897. Vergleichende Untersuchungen über die Funktion des Centralnervensystems der Arthropoden. Pflügers Arch. ges. Physiol., 68: 449-545.

Bоyсотт, B. B., 1954. Learning in Octopus vulgaris and other cephalopods. Pubbl. Staz. Zool. Napoli, 25: 67-93.

Cohen, M. J., 1960. The response patterns of single receptors in the crustacean statocyst. Proc. Roy. Soc. London, Ser. B, 152: 30-49.

Demoll, Reinhard, 1909. Über die Augen und die Augenstielreflexe von Squilla mantis. Zool. Jahrb., Abt. Anat. u. Ontog., $27:$ 171-212.

DijkgraAf, S., 1955. Rotationssinn nach dem Bogengansprinzip bei Crustaceen. Experientia, $11(10): 407-409$.

Dijkgraaf, S., 1956. Kompensatorische Augenstieldrehungen und ihre Auslosung bei der Languste (Palimurus vulgaris). Zeitschr.vergi. Physiol., 38: 491-520.

DijkgraAf, S., 1956. Über der kompensatorische Augenstielbewegungen bei Brachyuren. Pubbl. Staz. Zool. Napoli, 28: 341-358.

Duke-Elder, Sir Stewart, 1958. The Eye in Evolution. In: System of Ophthalmology. Ed. by S. Duke-Elder. Henry Kimpton, London. Vol. 1, pp. 1-843.

Ewald, W. F., 1914. Versuche zur Analyse der Licht- und Farbenreaktionen eines Wirbellosen (Daphnia pulex). Zeitschr. Sinnesphysiol., 48: 285-324.

Hertz, Mathilde, 1929-1934. Die Organisation des optischen Feldes bei der Biene. Zeitschr. vergl. Physiol., 8, 11, 14, 21.

Ingalls, A. G., 1954. The Amateur Scientist. Sci. Amer., 190(3) : 100-102.

Ingalls, A. G., 1954. The Amateur Scientist. Sci. Amer., 191(5) : 116-119.

Kunn, A., 1919. Die Orientierung der Tiere im Raum. Gustav Fischer, Jena.

Lindauer, M., And J. O. Nedel, 1959. Ein Schweresinnesorgan der Honigbiene. Zeitschr. vergl. Physiol., 42: 334-364.

Magnus, Rudolf, 1902. Die Pupillarreaktion der Octopoden. Pflïgers Arch. ges. Physiol., 92: 623-643.

Magnus, R., and A. DE Kleyn, 1921. Über die Funktion der Otolithen, Otolithenstand bei den tonischen Labyrinthreflexen. Pflïgers Arch. ges. Physiol., 186: 6-38.

Magnus, Rudolf, 1924. Korperstellung. In: Monographien aus dem Gesamptgebiet der Physiologie der Pflanzen und der Tiere. Ed. by M. Gildemeister. Julius Springer Verlag, Berlin. Vol. 6, pp. 1-740. 
Merton, P. A., 1956. Compensatory rolling movements of the eye. J. Physiol., 132: 25P-27P.

Milne, L. J., and Margery Milne, 1961. Scanning movements of the stalked compound eyes in crustaceans of the order Stomatopoda. In: Progress in Photobiology. Ed. by B. C. Christensen and B. Buchmann. Elsevier Publishing Co., Amsterdam; pp. 422-426.

Mittelstadt, Horst, 1950. Physiologie des Gleichgewichtssinnes bei fliegenden Libellen. Zeitschr. vergl. Physiol., 32: 422-463.

Muskens, L. J. J., 1904. Über eine eigentumliche compensatorische Augenbewegung der Octopoden mit Bemerkungen über deren Zwangbewegungen. Arch. Anat. Physiol. (Leipzig), 1904: 49-56.

NAgel, W. A., 1896. Über Kompensatorische Raddrehungen der Augen. Zeitschr. Psych. u. Physiol. Sinnesorq., 12: 331-342.

Prentiss, E. W., 1901. The otocyst of decapod Crustacea. Bull. Mus. Comp. Zool. (Harvard), 36: $167-251$.

Quesnel, V. C., 1956. Cyclorotating eyes in the tadpole of Phyllomedusa burmeisteri. Trinidad Field Naturalists' Club, 1956: 26.

Rochon-Duvigneaud, A.-J.-F., 1943. Les Yeux et la Vision des Vertébrés. Masson et Cie., Paris. 719 pp.

Schöne, Hermann, 1951. Die statische Gleichgewichtsorientierung dekapoder Crustaceen. Verh. deutsch. zool. Ges., Suppl., 16: 157-162.

Schöne, Hermann, 1954. Statozystenfunktion und statische Lageorientierung bei dekapoder Krebsen. Zeitschr. vergl. Physiol., 36: 241-260.

Schöne, Hermann, 1957. Kurssteurung Mittels der Statocysten (Messungen an Krebsen). Zeitsch. vergl. Physiol., 39: 235-240.

Schöne, Hermann, 1959. Die Lageorientierung mit Statolithenorganen und Augen. Ergeb. Biol., $21: 161-209$.

Walls, G. L., 1942. The Vertebrate Eye and Its Adaptive Radiation. Cranbrook Inst. Sci., Bloomfield Hills, Mich.; $14+785$ pp.

Weel, P. B. van, AND S. ThOR, 1936. Über die Pupillarreaktion von Octopus vulgaris. Zeitschr. vergl. Physiol., 23: 26-33.

Whitteridge, D., 1956. Machinery of posture. The Advancement of Science, no. 50, pp. 104-110.

Young, J. H., 1959. Morphology of the white shrimp Penaeus setiferus (Linnaeus 1758). Fishery Bull., 145 (U. S. Fish \& Wildlife Service, Washington, D. C., vol. 59) : 1-168.

Young, J. Z., 1960. The statocysts of Octopus vulgaris. Proc. Roy. Soc. London, Ser. B, $152: 3-29$.

Zотн, O., 1905. Augenbewegungen und Gesichtswahrnehmungen. Nagels Handb. Physiol., 3: 318-326. 

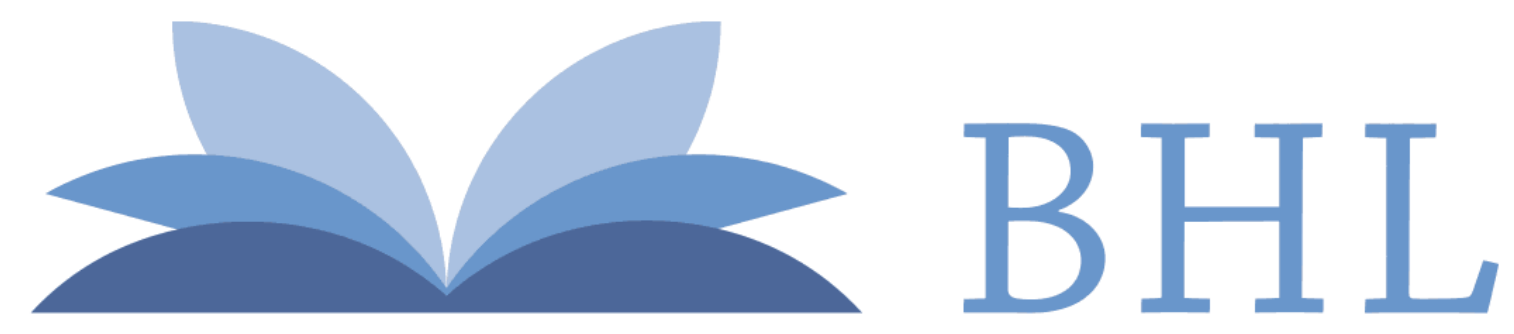

\section{Biodiversity Heritage Library}

Milne, Lorus J and Milne, Margery. 1965. "STABILIZATION OF THE VISUAL

FIELD." The Biological bulletin 128, 285-296. https://doi.org/10.2307/1539556.

View This Item Online: $\underline{\text { https://www.biodiversitylibrary.org/item/17320 }}$

DOI: https://doi.org/10.2307/1539556

Permalink: https://www.biodiversitylibrary.org/partpdf/24460

\section{Holding Institution}

MBLWHOI Library

\section{Sponsored by}

MBLWHOI Library

\section{Copyright \& Reuse}

Copyright Status: In copyright. Digitized with the permission of the rights holder.

License: http://creativecommons.org/licenses/by-nc-sa/3.0/

Rights: https://biodiversitylibrary.org/permissions

This document was created from content at the Biodiversity Heritage Library, the world's largest open access digital library for biodiversity literature and archives. Visit BHL at https://www.biodiversitylibrary.org. 